\title{
Potential impacts of climate change on groundwater resources: A multi-regional modelling assessment
}

\author{
Atie Hosseinizadeh ${ }^{1, *}$, Heidar Zarei ${ }^{1}$, Ali M Akhondali ${ }^{1}$, \\ Hesam Seyedkaboli ${ }^{2}$ and BABAK FARJAD ${ }^{3}$ \\ ${ }^{1}$ Department of Hydrology, Shahid Chamran University of Ahvaz, Ahvaz, Khuzestan, Iran. \\ ${ }^{2}$ Department of Civil Engineering, Jundi-Shapur University of Technology, Dezful, Khuzestan, Iran. \\ ${ }^{3}$ Department of Geomatics Engineering, University of Calgary, Calgary, AB, Canada. \\ ${ }^{*}$ Corresponding author.e-mail: atie_hoseinizade@yahoo.com
}

MS received 12 April 2018; revised 29 August 2018; accepted 19 November 2018; published online 13 May 2019

The complexity of understanding the groundwater resources in relation to climate change is caused by direct and indirect effects of climate change on hydrological processes. The study herein aims at implementing a physically based groundwater model to investigate the effects of climate change on groundwater system under 15 general circulation models (GCMs) in a semi-arid region from 2020 to 2044. A non-parametric probability density function estimator was used to quantify the level of uncertainties in the simulations. The method was applied to an area of $2073 \mathrm{~km}^{2}$ in southwest Iran, consisting of five plains: western Dez, eastern Dez, Sabili, Deymche and Lor. The results indicate that there is a decline in the recharge in April, May, June and October. The range of changes in the recharge was determined to be between $-10 \%$ and $+13 \%$ in the Sabili plain, $-6 \%$ and $+10 \%$ in the Deymche plain, $-4 \%$ and $+10 \%$ in the western-Dez plain, $-6 \%$ and $+26 \%$ in the eastern-Dez plain, and $-40 \%$ and $+100 \%$ in the Lor plain. The most significant decline in the groundwater level occurred in the Sabili plain in September. The largest uncertainty in the simulation of recharge under GCM scenarios was determined to be in August, September and December. This study highlights that climate change can have a significant effect on groundwater resources in the region that reinforces the need for groundwater management plans and a long-term perspective.

Keywords. Climate change; groundwater; hydrogeology; semi-arid region; uncertainty; Iran; nonparametric probability density function.

\section{Introduction}

An increase in atmospheric concentrations of the greenhouse gases (GHGs) - due to human activities since the 1950s (IPCC 2013) - has resulted in changes in magnitude and frequency of extreme climate events (Eckhardt and Ulbrich 2003). The concentration of GHGs is expected to rise during the present century as a result of global economic development (VanRoosmalen et al. 2009). The impact of rising GHG concentration on climate variables such as temperature and precipitation is inevitable (Ranjan et al. 2006; Scibek et al. 2007). The trend of global warming will continue for decades even if the present GHG concentration decreases at the global scale (Ali et al. 2012). The hydrological cycle and water resources have been affected due to alterations in precipitation, 
temperature, radiation and other climate variables (Kundzewicz et al. 2008; Quevauviller 2011).

Several methods exist for simulating the present and future climate variables with the most reliable tools being three-dimensional (3D) general circulation models (GCMs) (Zhao et al. 2005; Wilby and Harris 2006; IPCC 2007). However, there are high levels of uncertainties associated with those models caused by the selected parameters as well as the model structure that can lead to errors in forecasting and planning (Murphy et al. 2004; Grillakis et al. 2011; Van Pelt and Swart 2011). A study by Minville et al. (2008) has indicated that the largest uncertainty in climate impact studies is due to GCMs rather than downscaling methods, or hydrological models. Many other studies have suggested for using more than one GCM in climate impact studies (Prudhomme et al. 2003; Maurer 2007; Vicuna et al. 2007; Hellmann and Vermaat 2012; Kurylyk and MacQuarrie 2013; Hosseinizadeh et al. 2015; Farjad et al. 2016). These studies use an ensemble of runs from multiple GCMs to cover the range of uncertainty in future climate predictions. Although the range of uncertainty is taken into account, the degree of uncertainty needs to be quantified to provide the managers and planners with the level of confidence necessary for future projections.

In recent years, numerous studies have focused on the impact of climate change on surface water (Changxing et al. 2013; Claudia et al. 2013; Kobierska et al. 2013; Adams and Sada 2014), whereas the impact of climate on groundwater has received much less attention from the scientific community (Goderniaux et al. 2009; Jackson et al. 2011). Generally, most aspects of impacts of climate change on groundwater have remained unknown (Green et al. 2011) mainly due to difficulty in quantifying the relationship between the climate variables and groundwater components (Jyrkama and Sykes 2007). The impact of climate change on groundwater is important in arid and semiarid areas when groundwater is generally the main source of fresh water supply rather than the surface water (Kløve et al. 2011; Liu 2011; Jang et al. 2012; Pavelic et al. 2012; Touhami et al. 2015).

In this study, a groundwater model (MODFLOW) was used to investigate the effects of climate change on groundwater in the future. MODFLOW is a numerical model, which is one of the powerful tools for assessing the quantity and quality of groundwater (Thangarajan 2007; Konig and Weiss 2008; Gao 2011). The numerical models are difficult and time consuming (Rojas and Dassargues 2007). However, in recent decades, research that uses simulation models has been developed due to the improvement of high-speed computers (Singh 2013).

The simulated groundwater head by the MODFLOW model was developed under 15 GCMs combined with three scenarios of GHG emissions (A2, A1B and B1) in the Dezful aquifer. In addition, a non-parametric method, which estimates a probability density function (PDF), was used to investigate and quantify the level of uncertainties in the simulations.

\section{Study area and climate}

The Dezful plain with an area of $2073 \mathrm{~km}^{2}$ as the largest agricultural plain in the Khuzestan province is located in the northern part of that province in southwest of Iran. The plain contains five subplains: western Dez, eastern Dez, Sabili, Deymche and Lor (figure 1).

The Dez, Karkhe, Balarud, Kohnak and Shavoor rivers are located in the study area. The area plays an important role as a water resource and requires an efficient water resource management, efficient planning and a water policy review. Merely $4 \%$ of the region is classified as an urban area and the remaining is agricultural plains. All the plains have irrigation networks except the Lor plain. Recharge by irrigation networks increases in the Deymche plain due to the Keshtosanate-Karon which is an agricultural centre. Although, the irrigation networks play a major role in supplying water to crops, however, in some regions groundwater is also significantly utilised. Wheat, sugarcane and maize (32, 21 and $16 \%$ ) are the most common crops in this region. The cultivation period of wheat is between November and May, giving rise to the maximum recharge of groundwater by irrigation networks in this time period.

The study area has a semiarid climate with the mean monthly temperature of $36.5^{\circ} \mathrm{C}$ in July and $11.8^{\circ} \mathrm{C}$ in January. The mean monthly temperature data show a growing trend from 1985 to 2012 (figure 2). The mean of annual rainfall is 316.5 $\mathrm{mm}$. The mean annual precipitation has a decreasing trend for the long-term period of 1977-2012 (figure 3). The precipitation varies from $296 \mathrm{~mm}$ in the eastern Dez to $394 \mathrm{~mm}$ in the Lor.

The soil map of the region shows that most parts of the area have a low salinity and alkalinity limitation $(4<\mathrm{EC}<8 \mathrm{ds} / \mathrm{m}, \mathrm{ESP}<15 \%$ and $8<\mathrm{SAR}<13)$. 


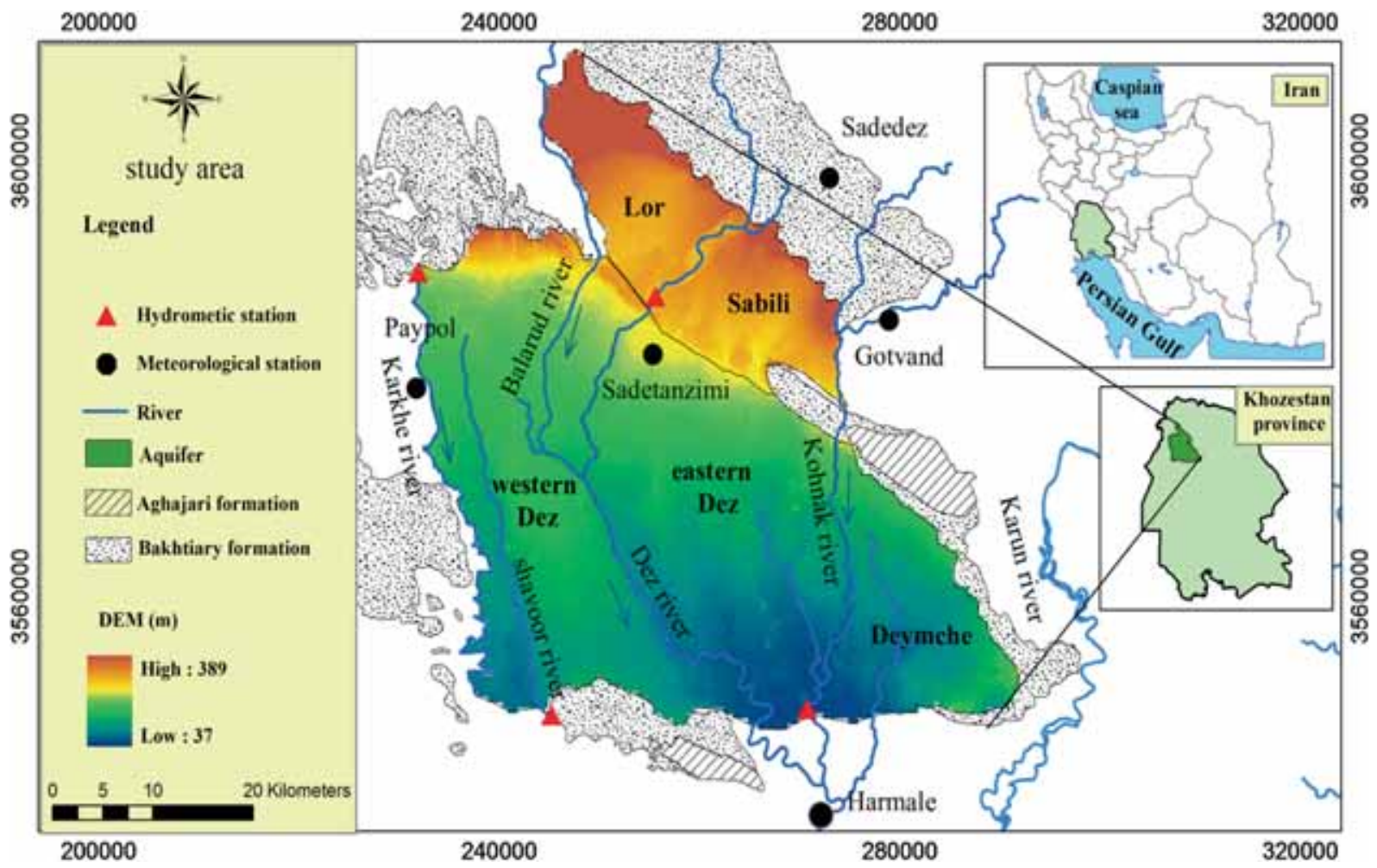

Figure 1. The map of the study area.

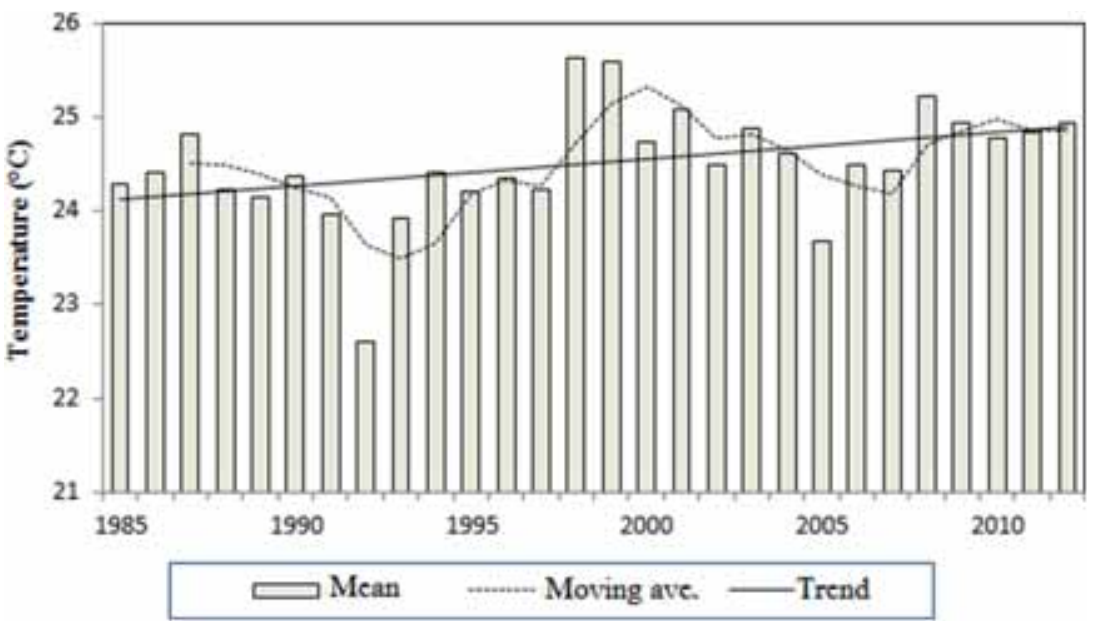

Figure 2. Mean temperature across Dezful between 1985 and 2012.

The area is composed of one distinct physiographic feature (i.e., river alluvial plain) (figure 4).

The Dezful aquifer with an average thickness of about $100 \mathrm{~m}$ is an unconfined aquifer system. There are over 2700 wells with pumping activity of 500 million $\mathrm{m}^{3}$ /year in this area. The general direction of groundwater flow in the area is from the north to the south. Recharge to the aquifer is through direct rainfall infiltration and return water from irrigation networks. The range of hydraulic conductivities is from $14 \mathrm{~m} /$ day for clay sediments in the Sabili to
$49 \mathrm{~m} /$ day for sandy deposits, particularly in the Lor subplain. The work herein uses 62 boreholes from 2006 to 2013.

\section{Method}

The methodological framework of this study consists of the following steps: (i) collecting and preparing observed data, (ii) set-up, calibration and validation of a groundwater model, (iii) selecting GCMs and downscaling GCMs output, 

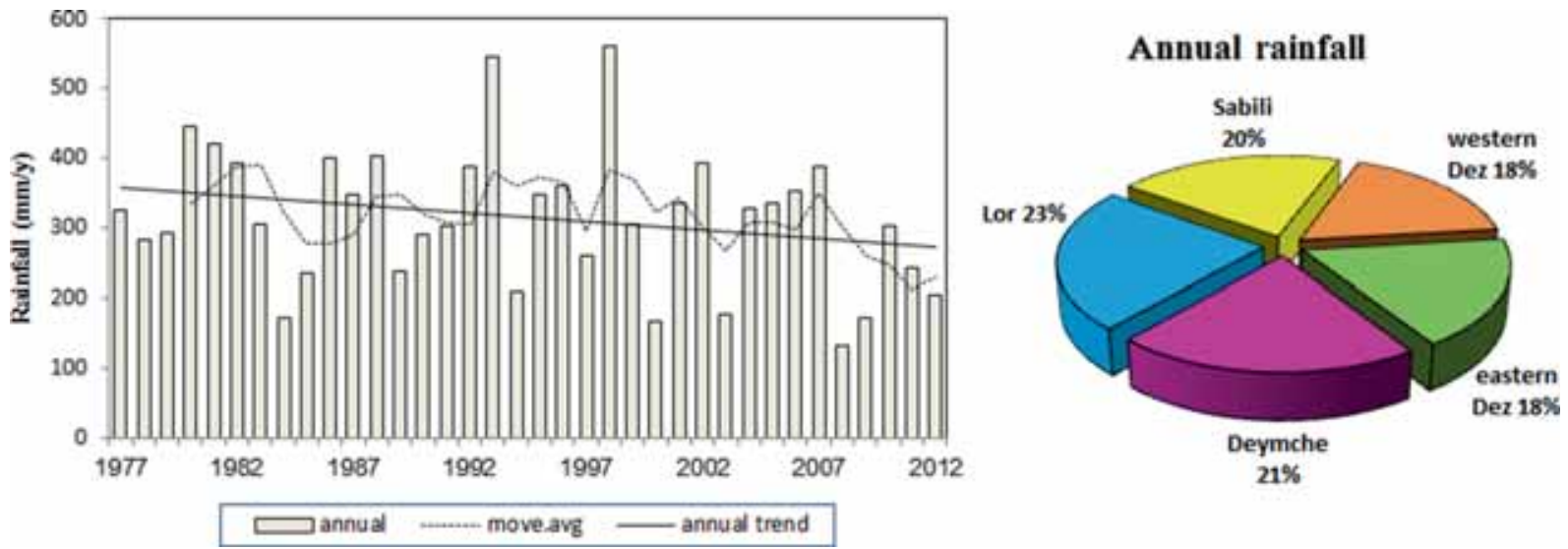

Figure 3. Mean long-term annual precipitation.

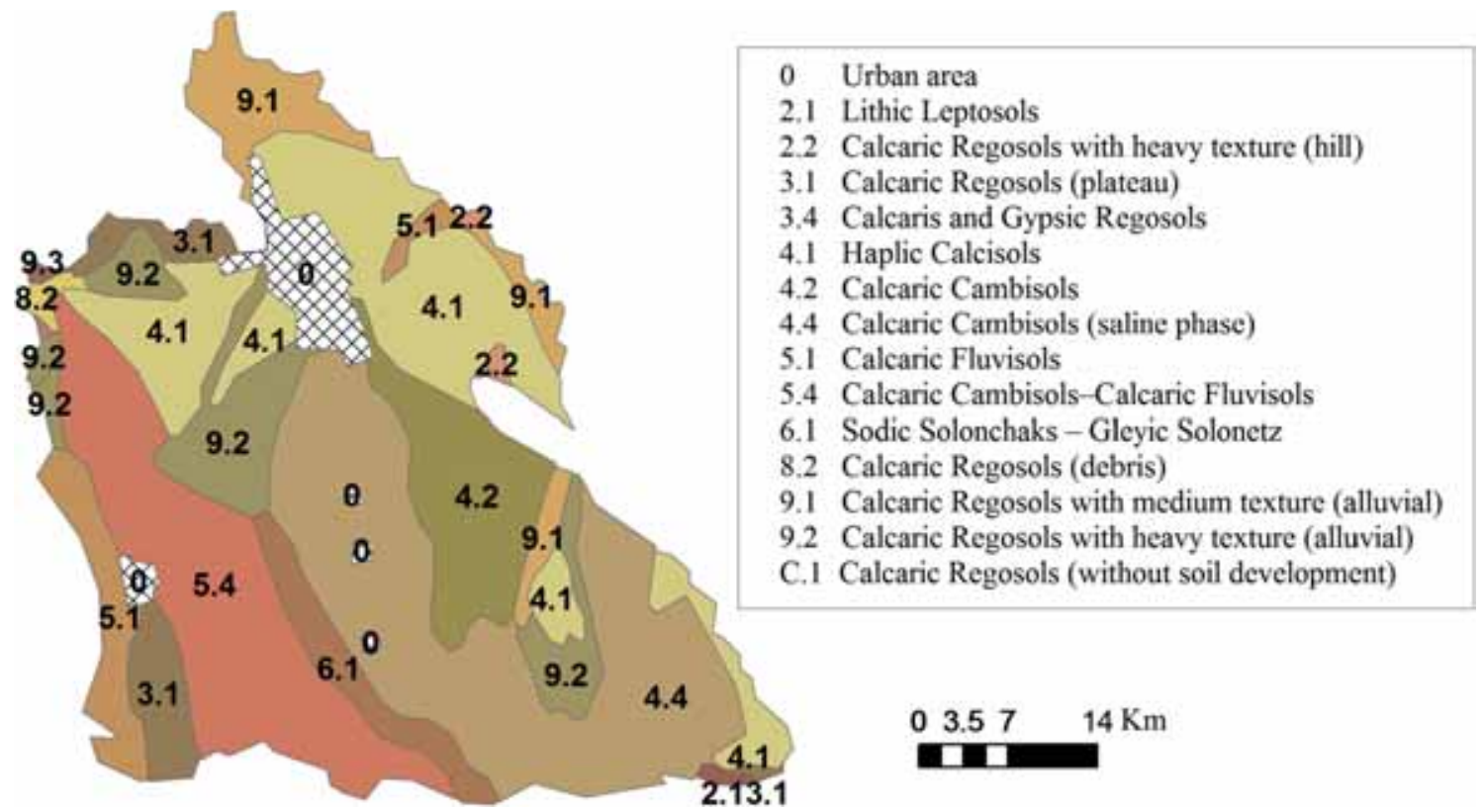

Figure 4. Soil map of study area classified by FAO method.

(iv) simulating groundwater components and (v) uncertainty assessment. These steps are described in the following.

\subsection{Observed data}

The observed data can be classified into three groups: (i) climate data, including daily maximum and minimum temperature, precipitation and potential evapotranspiration (ET) which were obtained from four climate index stations over 30 yr. The runs test (Wald-Wolfowitz test) and Mann-Whitney U test were employed to check the randomness and distribution of data, respectively. The Sadetanzimi climate station, which includes a complete series of climate data, was used as the reference climate station to estimate the missing climate data at the climate stations located in its neighbour (figure 5). (ii) The data related to both surface and sub-surface characteristics of plains such as topography, bedrock aquifer, thickness of the aquifer, soil were obtained from the Khuzestan Water and Power Authority. (iii) The hydraulic data such as groundwater recharge, irrigation and drainage systems, river hydraulic, wells are obtained from agricultural organisation and the Khuzestan Water and Power Authority. Hydrodynamic data on specific yield and hydraulic conductivity were obtained from pumping tests and wells (see equations 1 and 2). In this study, 

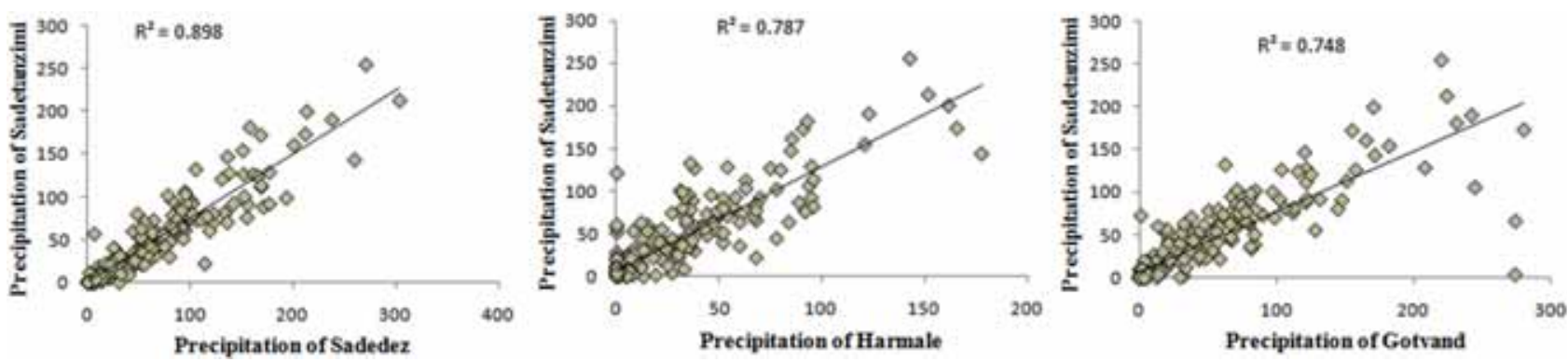

Figure 5. Correlations between precipitation data at Dez climate station and other stations in the study area.

the average of pumping test result from the two methods, Theis and Cooper-Jacob (see Appendix A1) (Cooper and Jacob 1946; Hantush 1961), is given below:

$$
\begin{aligned}
T & =\frac{Q}{4 \pi s} W(u), \\
S & =4 T \frac{t}{r^{2}}(u),
\end{aligned}
$$

where $s$ is the drawdown (change in hydraulic head at a point since the beginning of the test), $u$ is a dimensionless time parameter, $Q$ is the discharge (pumping) rate of the well $\left(\mathrm{L}^{3} / \mathrm{T}\right), T\left(\mathrm{~L}^{2} / \mathrm{T}\right)$ and $S$ (dimensionless) are the transmissivity and storativity of the aquifer around the well, $r$ is the distance from the pumping well to the point where the drawdown was observed, $t$ is the time since pumping began and $W(u)$ is the 'well function'.

\subsection{Groundwater model}

The following seven subsections provide explanations on the groundwater model including the conceptual model, boundary conditions, river, ET, recharge, numerical model, as well as calibration and validation.

\subsubsection{Conceptual model}

The comprehensive groundwater program, groundwater modelling system (GMS), which provides an interface to the groundwater flow model, MODFLOW, was used for groundwater and subsurface simulations in a $3 \mathrm{D}$ environment. MODFLOW is a cell-centred, finite-difference groundwater flow model that solves the 3D groundwater flow equation developed by the United States Geological Survey (McDonald et al. 1988; Khadri and Pande 2016). The partial differential equation that describes the 3D movement of groundwater of constant density through a porous earth material under equilibrium conditions is as follows:

$$
\begin{gathered}
\frac{\partial}{\partial x}\left(K_{x x} \frac{\partial h}{\partial x}\right)+\frac{\partial}{\partial y}\left(K_{y y} \frac{\partial h}{\partial y}\right) \\
+\frac{\partial}{\partial z}\left(K_{z z} \frac{\partial h}{\partial z}\right)=0
\end{gathered}
$$

where $K_{x x}, K_{y y}$ and $K_{z z}$ are the hydraulic conductivities in the $x, y$ and $z$ directions, respectively. The hydraulic conductivities are assumed to be parallel to the axes of hydraulic conductivity $(\mathrm{L} / \mathrm{T})$ and $h$ is the potentiometric head (L).

The first step in the modelling of groundwater is papering a conceptual model. This step is the most important part of the modelling process. This is because it simplifies the interaction between components of the system and organises them for easy analysis of the system.

In this study, the input data for the conceptual model come from three types of coverage layers: (i) the first coverage was used to define source and sinks such as river and pumping well, (ii) the second coverage was used to define the areal attributes such as recharge, ET, hydraulic conductivity, specific yield and boundary conditions and (iii) this coverage was used to define the groundwater table measured at 62 observation wells. Based on a defined set of observation wells and solution to groundwater simulations, the GMS interpolates the computed solution to observation wells and then the error (computed-observed) will be displayed graphically (Froukh 2002).

\subsubsection{Boundary condition}

Two boundary conditions, general head and no-flow, were defined for the model. The flow of water in and out of the general head boundary (GHB) cells depends on the groundwater gradient flow. There is no groundwater flow in and out in the system when a no-flow boundary condition is defined for the model. In other words, there are no water interactions between the aquifer and the 


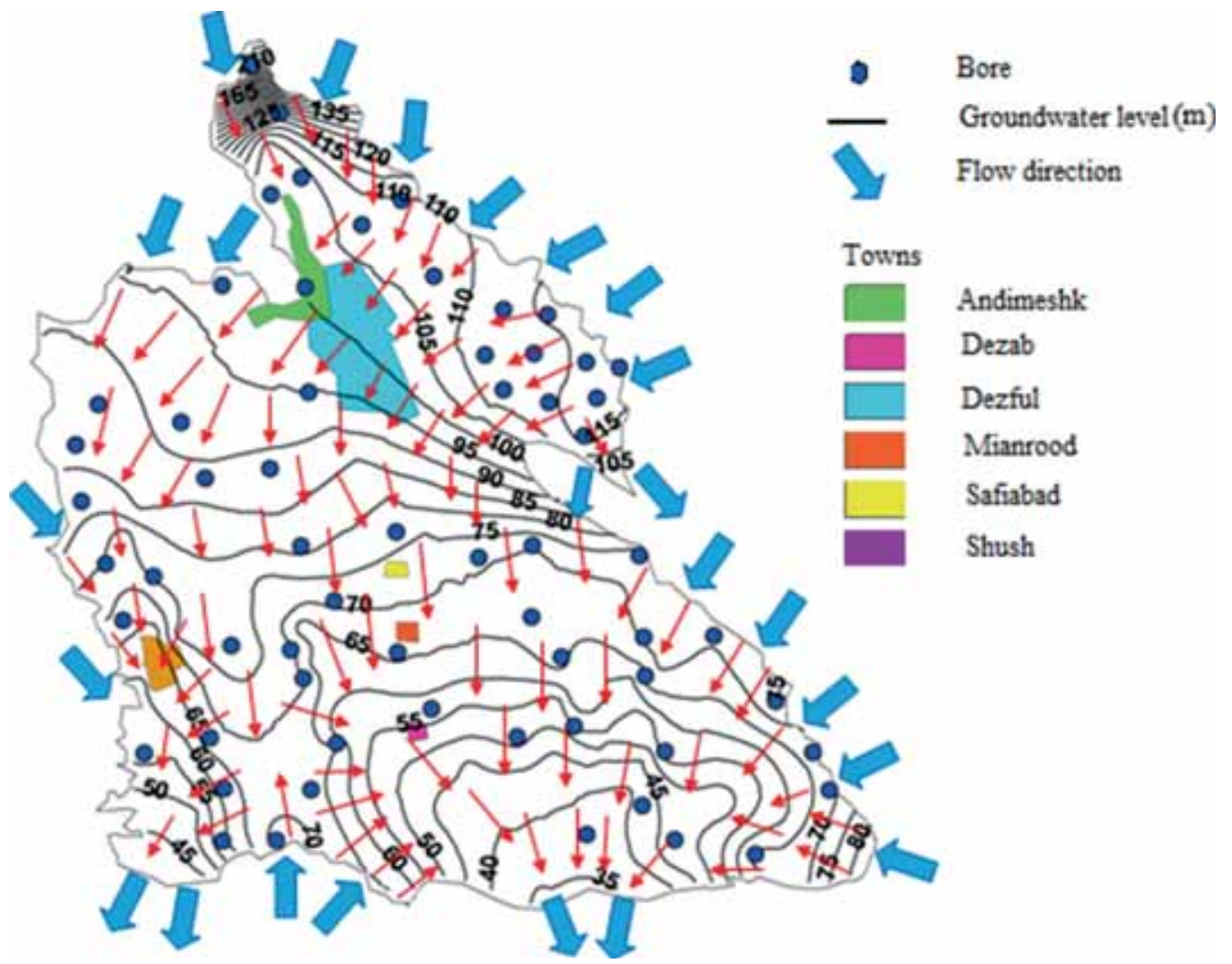

Figure 6. Groundwater level and boundary condition of study area.

surrounding areas. To determine the location of GHB cells and hydraulic head of each cell, the groundwater head counter of the boreholes was identified for each time step (figure 6). Then, the flow of water in and out of boundary conditions was defined based on the hydraulic gradient. Water level and conductance coefficient play important roles in estimating the exchange rates of the flow at the boundary for each GHB cell:

$$
C=W \times L\left(\frac{k}{D}\right)
$$

where $C$ is the conductance $\left(\mathrm{L}^{2} / \mathrm{T}\right), k$ is the average hydraulic conductivity $(\mathrm{L} / \mathrm{T}), W$ is the thickness of the saturated aquifer perpendicular to the flow direction (L), $L$ is the boundary length perpendicular to the flow direction $(\mathrm{L})$ and $D$ is the distance from the general head boundary to the model boundary $(\mathrm{L})$.

\subsubsection{River}

River package in MODFLOW was used to include river networks in the groundwater mode. In this model, the interaction between the river and the aquifer exists only where the water table is higher than the base of the riverbed sediments. The required data for this package are the head stage, bottom elevation and conductance. The information related to water level and river bottom elevation was obtained from river profiles at different locations in the study area. Conductance coefficient of the bed was calculated based on the Darcy's law as the following:

$$
C=\frac{K}{t} A
$$

where $k$ is the hydraulic conductivity $(\mathrm{L} / \mathrm{T}), t$ is the thickness of the sediment of the river $(\mathrm{L})$ and $A$ is an area of the stream bed $\left(\mathrm{L}^{2}\right)$.

\subsubsection{Evapotranspiration}

ET from groundwater can occur when there is a shallow groundwater table (Chen et al. 2013) which can be calculated as follows:

$$
Q=Q_{\mathrm{ETM}} \times\left(1-\frac{D}{X}\right),
$$




\section{ET surface}

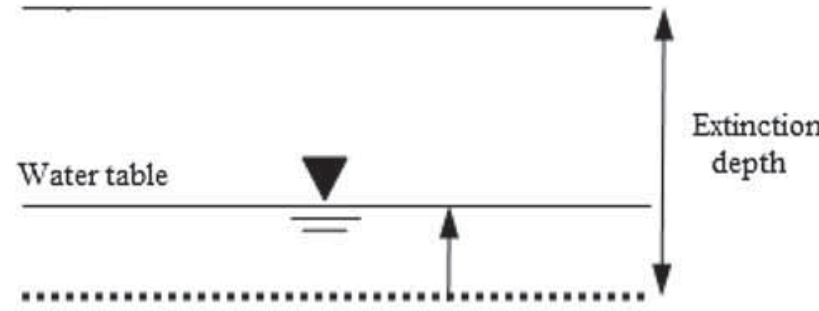

Hydraulic head

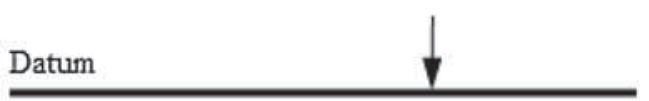

Figure 7. The ET model (Banta 2000).

where $Q$ is the ET from the groundwater $\left(\mathrm{L}^{3} / \mathrm{T}\right)$, $Q_{\mathrm{ETM}}$ is the maximum ET rate $\left(\mathrm{L}^{3} / \mathrm{T}\right)$ from the surface, $D$ is the depth of groundwater (L) and $X$ is the extinction depth $(\mathrm{L})$. If the groundwater depth is equal or greater than the extinction depth, the ET from aquifer will stop. But if the groundwater depth is less than the extinction depth, ET occurs at a linear fraction or an exponential rate ( $\mathrm{Li}$ et al. 2008; Luo et al. 2012) (figure 7). First, the areas where the groundwater depth is below the extinction depth were identified. The maximum ET rates were estimated based on ET data from meteorological stations and the depth of groundwater obtained from observation wells.

\subsubsection{Recharge}

Recharge is a very important input for groundwater modelling that can be calculated through simple to complex models (Ali et al. 2012; Chen et al. 2012). One of the most widely used methods for estimating groundwater recharge rates is building a relationship between the recharge and precipitation. There are several parameters that can influence groundwater recharge such as topography, slope, soil, copping patterns, drainage systems and artificial recharge. These parameters were created as geographic information system (GIS) layers to apply in the model. However, some of the layers such as land-use classes and cropping patterns were created as discrete features while other layers such as topography and ground surface level elevation were built as continuous features which may not represent real life. In this study, this complexity was addressed using a fuzzy logic method which is based on a matter of degree (Gerner et al. 2012).
In fuzzy logic, a proposition is not absolutely true or absolutely false. A membership function, $\mu_{\mathrm{A}}$, is used in a fuzzy set to define the degree of membership. The value of the membership function changes from 0 to 1 . The values of 0 and 1 indicate no membership and full membership, respectively, and values in between indicate partial membership. If $U$ represents a set (universe), $A$ is a fuzzy subset of $U$ if $A$ is a set of ordered pairs: $A=\left\{\left[u, \mu_{\mathrm{A}}(u)\right], u \in U\right\}$, where $\mu_{\mathrm{A}}(u)$ is the degree of membership of $u$ in $A$ (Klir and Yuan 1995; Coppola et al. 2002). For the membership function of a fuzzy set ' $A$ ',

$$
A: X \rightarrow[0,1] .
$$

Fuzzy rules define a function set of ordered pairs with the Cartesian product of fuzzy classes, defined on each of the input variables, and also a range of the fuzzy set defined on the output variable. The total possible number of rules is associated with the number of classes for each input variable.

To implement the fuzzy approach, first, the spatial data layers such as soil, cropping patterns, slope and topography were studied using fuzzy models (figure 8). The model was extended to input flow such as precipitation and agricultural irrigation. Rainfall data were collected from several stations in the study area for $30 \mathrm{yr}$. The input water from irrigation networks was calculated using network discharge and position. This information is the database for fuzzification of the fuzzy areas using GIS. The calculated fuzzy recharge areas by GIS are used as inputs into the recharge package of MODFLOW.

\subsubsection{Numerical model}

A 3D numerical groundwater model was implemented in $500 \times 500 \mathrm{~m}$ grid networks. The model was capable of calculating groundwater heads, water flow budget, water flow velocity and flow directions. The information related to topography of surface, bedrock and initial head of groundwater was used in the $2 \mathrm{D}$ scatter data as point layers (figure 9). Each of these layers was interpolated in the GMS environment and incorporated in the numerical model. The interpolation methods were selected based on evaluating the semivariograms of different interpolation methods. Kriging-Gaussian was selected to interpolate surface and bedrock and Kriging-Exponential was used for initial head groundwater. 

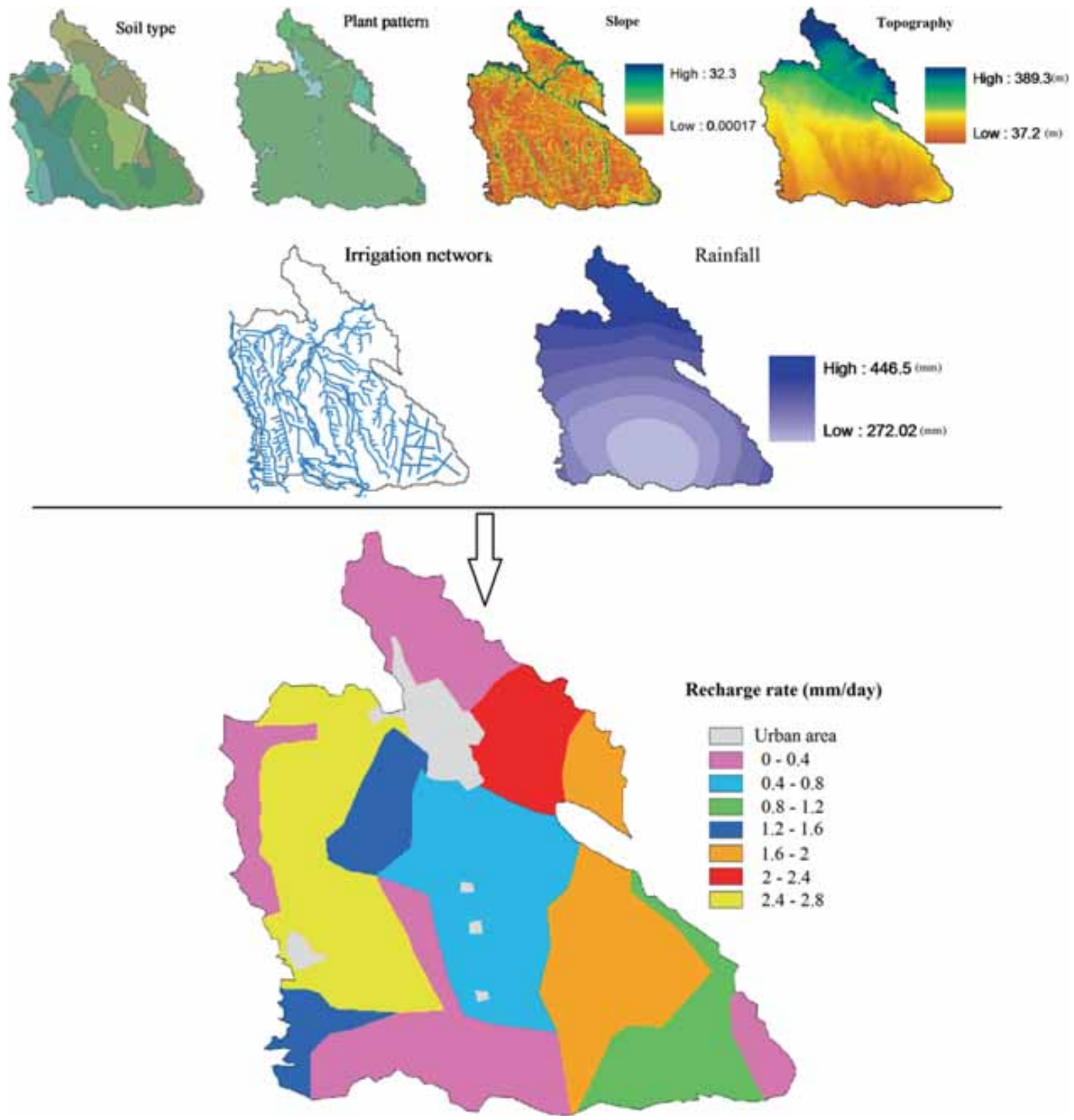

Figure 8. Map of groundwater recharge areas identified using fuzzy approach calculating with GIS.

\subsubsection{Calibration and validation}

The groundwater model was calibrated in both steady state and transient condition. First, the steady-state model was calibrated automatically by PEST method (Doherty 2015). This was done to optimise the relationship between the steadystate observed and simulated hydraulic head in September 2006. In the second step, by trialand-error calibration, several parameters such as recharge rate, the conductance of river bed, hydraulic conductivities were adjusted until best results were obtained between the observed and simulated heads. The observation head of groundwater is compared with the calculation head using 62 boreholes. The model was calibrated in transient condition (2006-2012) using both automatic and manual methods by mentioned parameters and also specific yields, and was validated from 2012 to 2013. Finally, mean error, mean absolute error and RMSE (root mean squared error) were obtained as $-0.001,0.5$ and less than $0.6 \mathrm{~m}$, respectively, for the calibrated model. Figure 10 shows how the simulation error of the model is decreasing corresponding to an increase in simulation runs. 

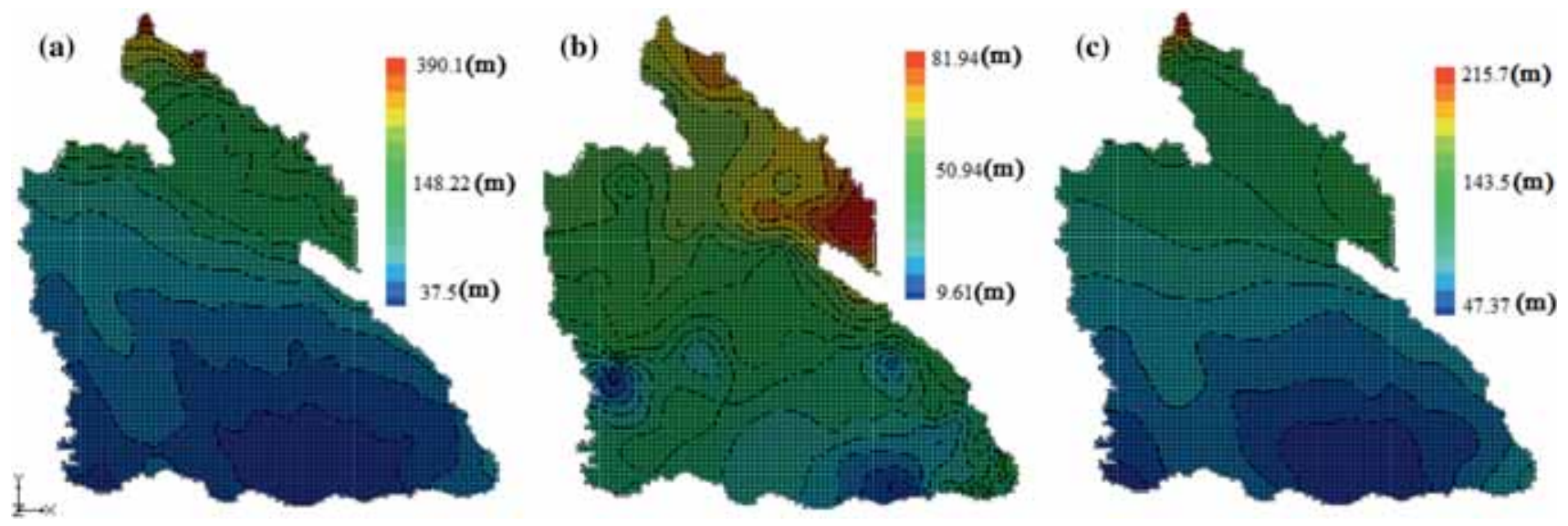

Figure 9. Interpolated data of (a) topography, (b) bedrock and (c) initial head of groundwater.

\section{Simulation \& Error}

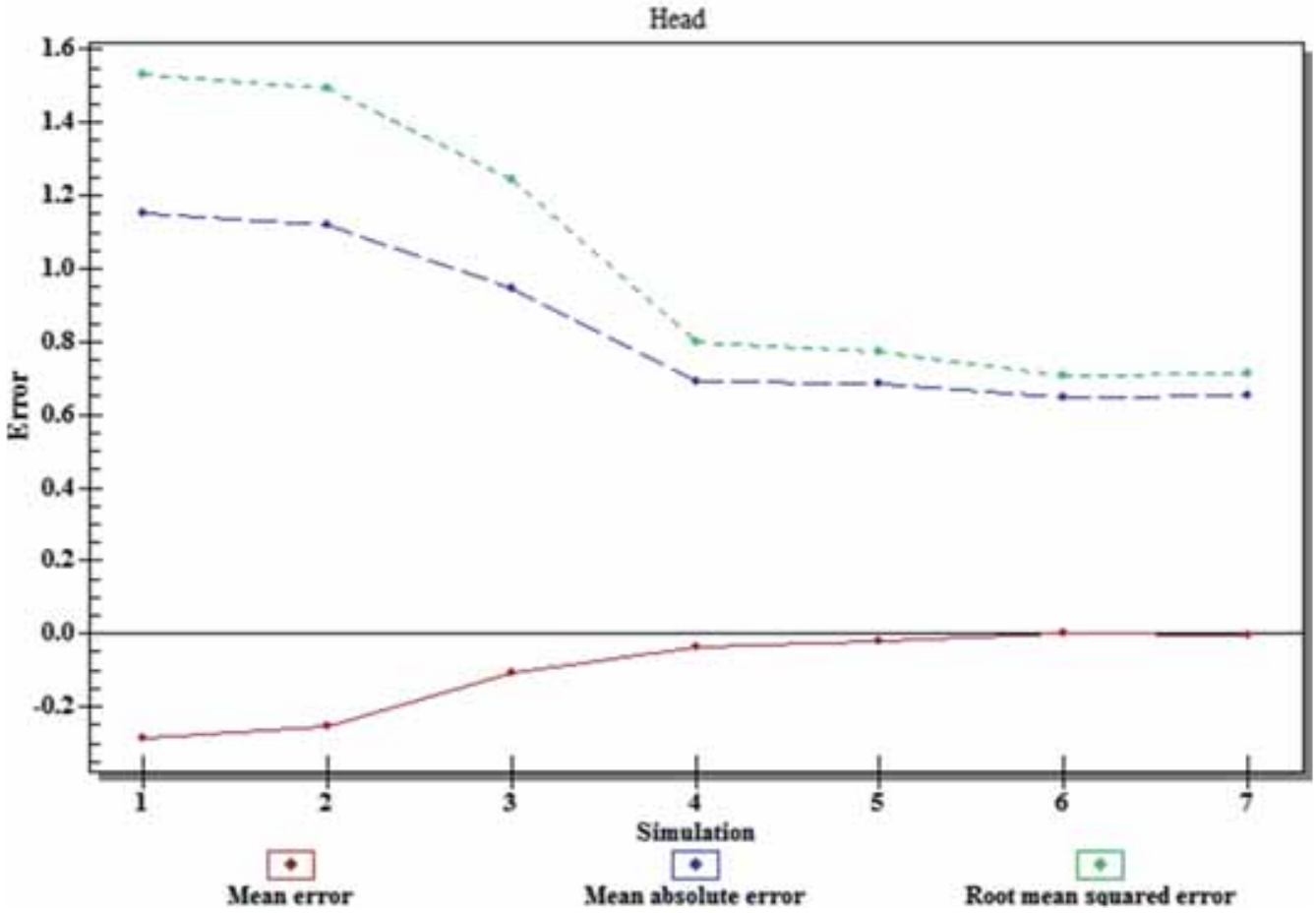

Figure 10. The model performance for different simulation runs.

\subsection{Climate change}

To understand the future climate change in the study area, 15 GCMs and three scenarios from the Intergovernmental Panel on Climate Change (IPCC) AR4 Special Report on Emissions Scenarios (SRES) (described in Appendix A2) were considered in this study (table 1). GCM-AR4 was compared with previous studies in the region. However, we recommend considering the GCM-AR5 in future works. The baseline data were used from 1985 to 2009 from four meteorological stations.

Since GCM outputs have a coarse resolution, they are not applicable for regional studies
(Aronica et al. 2005; Ekström et al. 2005; Laprise 2008; Forsythe et al. 2014). The output of GCMs was downscaled based on the data of local meteorological stations and downscaling techniques to investigate the effects of climate change in regional scale (Barnett et al. 2004; Hewitson and Crane 2006; Stoll et al. 2011; Candela et al. 2012). In this study, the LARS-WG model was used to downscale the output of GCMs. The LARS-WG is a stochastic weather generator which can be used for the simulation of weather data at a single site, under both current and future climate conditions. This model is cable of generating the patterns of wet and dry periods, daily precipitation and solar 
Table 1. GCMs considered in this study (IPCC 2007).

\begin{tabular}{|c|c|c|c|}
\hline Number & Model & $\begin{array}{l}\text { Emission } \\
\text { scenarios }\end{array}$ & Organiser \\
\hline 1 & CGCM3T47 & $\mathrm{A} 1 \mathrm{~B}, \mathrm{~A} 2, \mathrm{~B} 1$ & $\begin{array}{l}\text { Canadian Centre for Climate Modelling and Analysis } \\
\text { (CCCma, Canada) }\end{array}$ \\
\hline 2 & CNRMCM3 & $\mathrm{A} 1 \mathrm{~B}, \mathrm{~A} 2, \mathrm{~B} 1$ & Center National Weather Research (CNRM, France) \\
\hline 3 & CSIROMk3.5 & $\mathrm{A} 1 \mathrm{~B}, \mathrm{~A} 2, \mathrm{~B} 1$ & $\begin{array}{l}\text { Commonwealth Scientific and Industrial Research } \\
\text { Organization (CSIRO, Australia) }\end{array}$ \\
\hline 4 & ECHAM5 & $\mathrm{A} 1 \mathrm{~B}, \mathrm{~A} 2, \mathrm{~B} 1$ & Max Planck Institute for Meteorology (Germany) \\
\hline 5 & ECHO-G & $\mathrm{A} 1 \mathrm{~B}, \mathrm{~A} 2, \mathrm{~B} 1$ & $\begin{array}{l}\text { Meteorological Institute of the University of Bonn } \\
\text { (Germany) }\end{array}$ \\
\hline 6 & FGOALS-g1 & $\mathrm{A} 1 \mathrm{~B}, \mathrm{~B} 1$ & Institute of Atmospheric Physics (IAP, China) \\
\hline 7 & GFDMCL2.1 & $\mathrm{A} 1 \mathrm{~B}, \mathrm{~A} 2, \mathrm{~B} 1$ & $\begin{array}{l}\text { Geophysical Fluid Dynamics Laboratory } \\
\text { (GFDL, USA) }\end{array}$ \\
\hline 8 & GISS-ER & $\mathrm{A} 1 \mathrm{~B}, \mathrm{~A} 2, \mathrm{~B} 1$ & Goddard Institute for Space Studies (GISS, USA) \\
\hline 9 & $\mathrm{HadCm} 3$ & $\mathrm{~A} 1 \mathrm{~B}, \mathrm{~A} 2, \mathrm{~B} 1$ & Hadley Centre (UK) \\
\hline 10 & HadGEM1 & $\mathrm{A} 1 \mathrm{~B}, \mathrm{~A} 2$ & Hadley Centre (UK) \\
\hline 11 & INGV-SXG & $\mathrm{A} 1 \mathrm{~B}, \mathrm{~A} 2$ & $\begin{array}{l}\text { Istituto Nazionale di Geofisica e Vulcanologia } \\
\text { (NIGV, Italy) }\end{array}$ \\
\hline 12 & INMCM3 & $\mathrm{A} 1 \mathrm{~B}, \mathrm{~A} 2, \mathrm{~B} 1$ & Institute of Numerical Mathematics (INM, Russia) \\
\hline 13 & MIROC3.2 & $\mathrm{A} 1 \mathrm{~B}, \mathrm{~A} 2, \mathrm{~B} 1$ & $\begin{array}{l}\text { National Institute for Environmental Studies } \\
\text { (NIES, Japan) }\end{array}$ \\
\hline 14 & MRI CGCM2.3 & $\mathrm{A} 1 \mathrm{~B}, \mathrm{~A} 2, \mathrm{~B} 1$ & $\begin{array}{l}\text { Meteorological Research Institute, Japan } \\
\text { Meteorological Agency }\end{array}$ \\
\hline 15 & NCARPCM & $\mathrm{A} 1 \mathrm{~B}, \mathrm{~A} 2, \mathrm{~B} 1$ & $\begin{array}{l}\text { National Center for Atmospheric Research } \\
\text { (NCAR, USA) }\end{array}$ \\
\hline
\end{tabular}

See http://www.cccsn.ec.gc.ca.

radiation (Semenov and Barrow 2002; Semenov and Stratonovitch 2010). The process of LARSWG can be divided into three distinct steps:

1. Observed weather data were analysed to determine their statistical characteristics.

2. The statistical characteristics of the observed and synthetic weather data were assessed by different statistical tests such as the $Q$ and $F$ tests, as well as the $\chi^{2}$ test to see if there is any statistically significant difference between the data.

3 . The parameter files derived from the observed weather data during the model calibration process were used to generate synthetic weather data. Synthetic data corresponding to a particular climate change scenario were generated by applying GCM-derived changes in precipitation, temperature and solar radiation to the LARS-WG parameter files.

\subsection{Uncertainty}

In this study a non-parametric method, the Kernel estimation, was used to assess the model uncertainty. This method estimates a PDF function for climate variables obtained from the output of
GCMs, such as precipitation and temperature. In the non-parametric method, the density function $(f)$ is unknown and should be determined using the statistical analysis. The Kernel estimator with centre $K$, which is a symmetric density function such as Gaussian density, is defined as follows (Solaiman and Simonovic 2011):

$$
\hat{f}(x)=\frac{1}{n h} \sum_{i=1}^{n} K\left(\frac{x-X_{i}}{h}\right),
$$

where $K\left(\left(x-X_{i}\right) / h\right)$ is the weight or kernel function applied to satisfy criteria such as symmetry, finite variance and integrates to unity. The kernel density estimation highly depends on the selection of the smoothing parameter, bandwidth $(h)$ and the type of kernel function $K$.

\section{Results and discussion}

The following five subsections provide a discussion of results on groundwater balance, temporal relationship between the precipitation and ground- 
water level, determination of hydraulically connected groundwater and surface water resources, impact of climate change on precipitation and temperature, and assessment of uncertainties.

\subsection{Groundwater balance}

Simulation results of groundwater balance components are illustrated in figure 11. The less
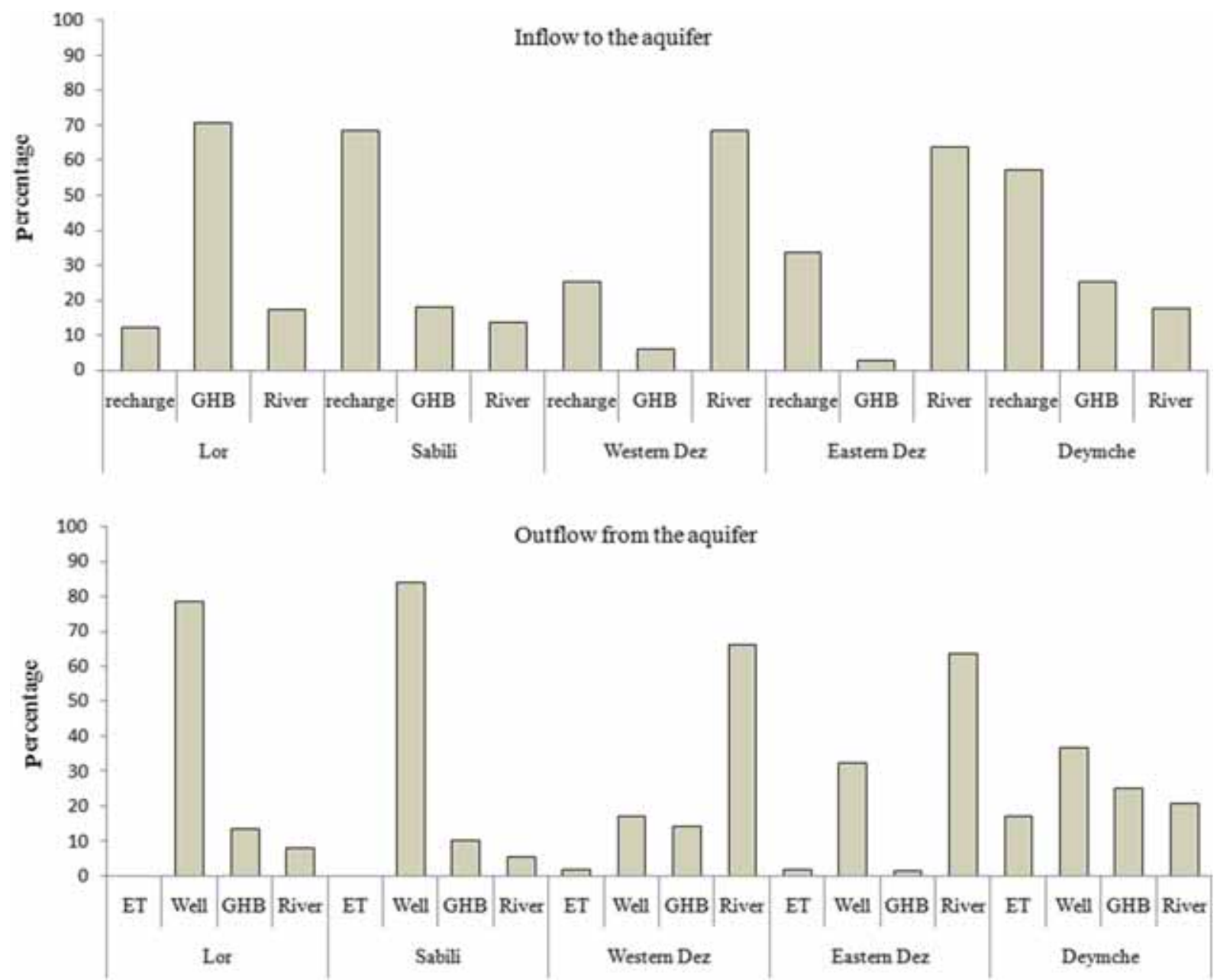

Figure 11. Groundwater balance components for the Dezful plain.

Table 2. Cross-correlations between precipitation and average groundwater level.

\begin{tabular}{lcccccc}
\hline $\begin{array}{l}\text { Lag } \\
\text { (month) }\end{array}$ & Lor & Sabili & $\begin{array}{c}\text { Destern } \\
\text { Dez }\end{array}$ & $\begin{array}{c}\text { Eastern } \\
\text { Dez }\end{array}$ & Deymche & $\begin{array}{c}\text { Total study } \\
\text { area }\end{array}$ \\
\hline 0 & 0.635 & $\mathbf{0 . 6 8 5}$ & 0.473 & 0.437 & 0.522 & 0.4 \\
1 & $\mathbf{0 . 7 0 5}$ & 0.653 & $\mathbf{0 . 6 8 3}$ & $\mathbf{0 . 6 8 3}$ & $\mathbf{0 . 7 0 2}$ & $\mathbf{0 . 5 8 9}$ \\
2 & 0.684 & 0.679 & 0.671 & 0.63 & 0.603 & 0.392 \\
3 & 0.53 & 0.531 & 0.412 & 0.379 & 0.402 & 0.33 \\
4 & 0.539 & 0.456 & 0.425 & 0.427 & 0.364 & 0.3 \\
5 & 0.456 & 0.457 & 0.324 & 0.299 & 0.289 & 0.249 \\
6 & 0.251 & 0.264 & 0.065 & 0.057 & 0.046 & 0.029 \\
7 & 0.142 & 0.083 & 0.037 & 0.01 & -0.008 & -0.004 \\
8 & 0.122 & 0.045 & 0.027 & -0.024 & 0.012 & -0.015 \\
9 & 0.159 & 0.175 & 0.067 & 0.017 & 0.194 & 0.096 \\
10 & 0.183 & 0.253 & 0.124 & 0.057 & 0.248 & 0.059 \\
11 & 0.283 & 0.321 & 0.219 & 0.138 & 0.221 & 0.155 \\
12 & 0.289 & 0.323 & 0.164 & 0.105 & 0.245 & 0.153 \\
\hline
\end{tabular}

The maximum values are indicated in bold. 
groundwater recharge occurs in the Lor plain compared to other plains when there are no irrigation systems in this plain. However, this plain has a high hydraulic gradient which can facilitate flow recharge into the aquifer. On the other hand, the most groundwater recharge occurs in the Sabili plain due to the largest irrigation systems in this plain compared to others. The largest amount of groundwater extraction occurs in the Lor and Sabili subplains through 500 wells (between 78 and $84 \%$ of outflow from the aquifer) located in these plains.

Rivers play important roles in groundwater balance in the western and eastern Dez plains as the longest and highest discharge river systems take place in these plains. The Deymche plain receives a relatively high amount of recharge ( $57 \%$ of inflow to the aquifer) due to Keshtosanate-Karon irrigation systems. However, it losses relatively high amount (17\% of outflow from the aquifer) of ET due to a shallow groundwater table comparison with other plains.

\subsection{Temporal relationships between the precipitation and groundwater level}

The relationships between groundwater tables and precipitation were assessed to determine lag time for responses of groundwater to precipitation events (table 2). Simulation results show the groundwater table in relation to precipitation events within a lag time of 1 month, except in the Sabili plain. The lag time for the Sabili plain occurs in 1-2 days. The correlation between the

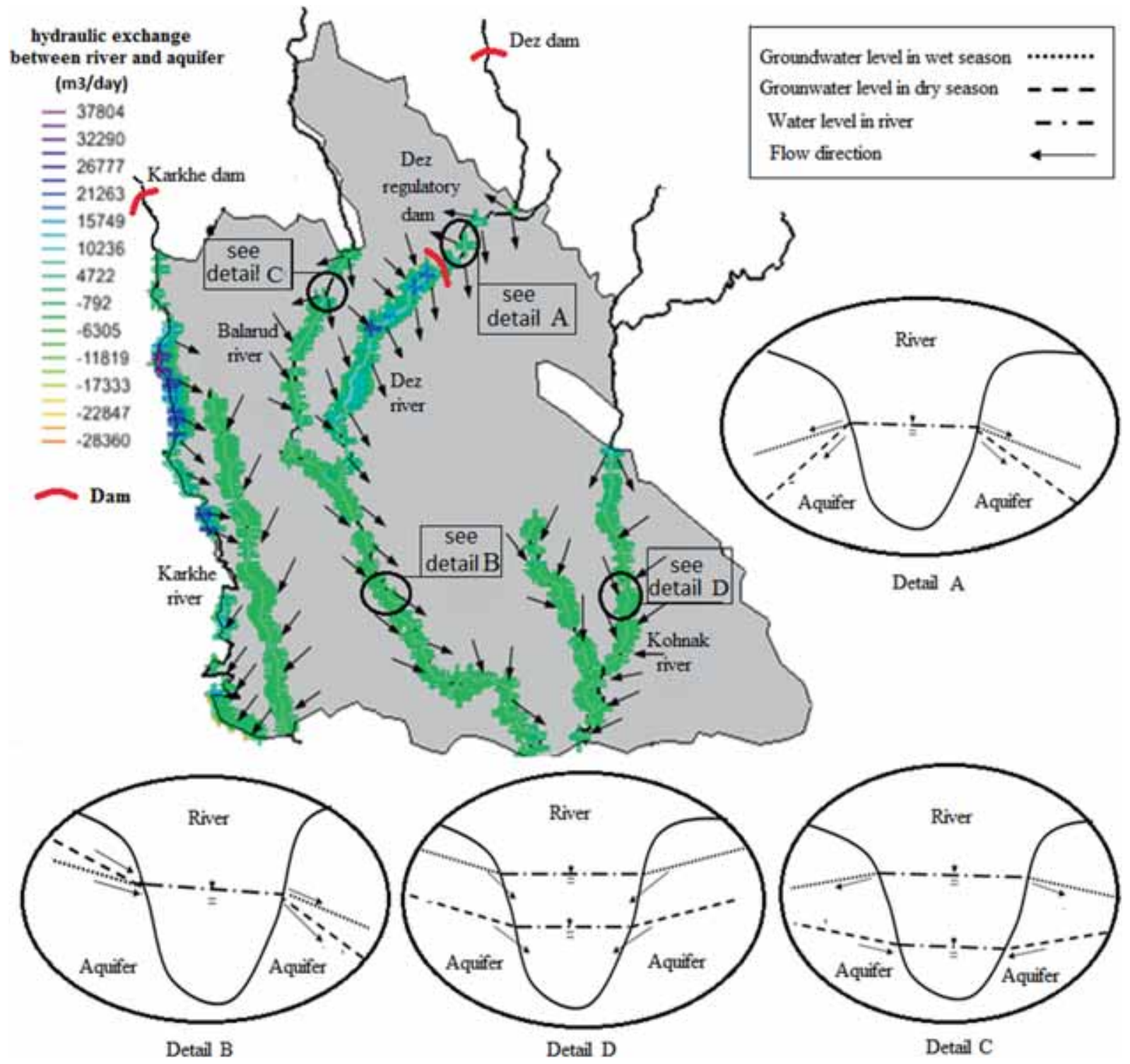

Figure 12. Interactions between river and groundwater in May 2012. 
groundwater table and precipitation ranges between 0.589 and 0.705 .

\subsection{Determination of hydraulically connected groundwater and surface water resources}

The highest surface and groundwater interactions occur along the Dez River, which is located between the Dez Dam and the Balarud River. However, this is not the case for the upstream of the Dez River, where there is a deep groundwater table, and consequently, the flow only occurs from the river to the aquifer. On the other hand, the highest discharge occurs in the downstream of the Dez River. The highest recharge and discharge of the Karkhe River takes place at the upstream and downstream of the river, respectively. The surface and groundwater interactions in the dry and wet seasons are illustrated for four locations along the rivers in figure 12. Two important concepts to be understood in this regard are as follows:

1. There is an increase in the groundwater table in the wet season due to the amount of water entering the groundwater system from both precipitation and irrigation systems. There are no significant changes in the river flow in the wet season when the flow in the Dez and Karkhe rivers is regulated.

2. In the downstream of the Dez River, the recharge and discharge occur in both wet and dry seasons through the east and west parts of the watershed, respectively. This is due to a lower water table in the east part of the plain, and a higher water table in the west (as a result of the irrigation systems).

\subsection{Climate change impact on precipitation and temperature}

Results show that the mean temperature increases under 42 GCM scenarios in the plain for the period 2020-2044 (figure 13). The largest rise in the temperature occurs in May when it is the harvest time of the dominant crop (wheat) in the region, which can be a concern for farmers and policymakers. The highest increase in the temperature $\left(3.4^{\circ} \mathrm{C}\right)$ belongs to the Gotvand station in the east of the plain. The rise in the mean temperature is more pronounced in the dry season compared to the wet season.
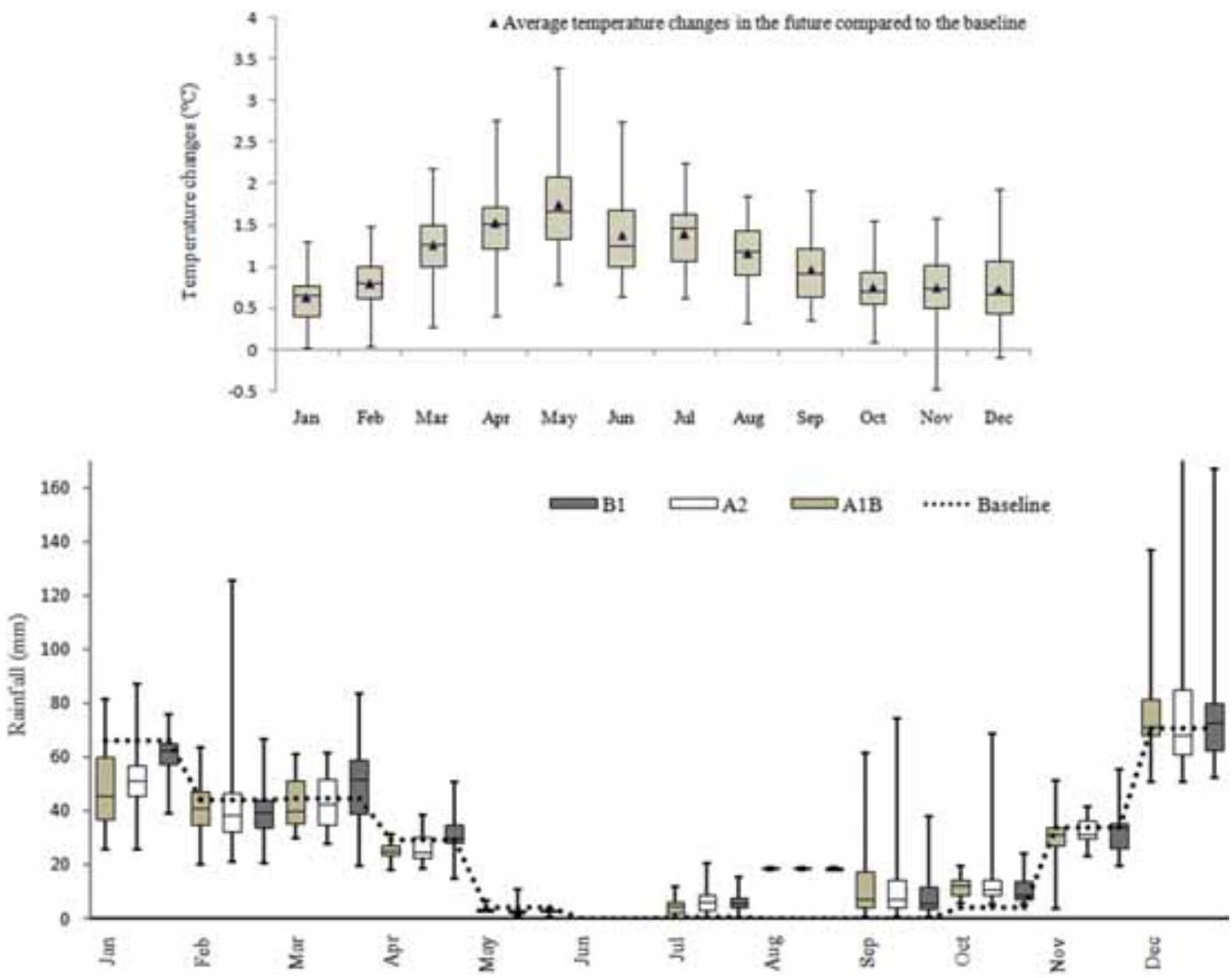

Figure 13. Average rainfall and temperature changes in the future compared to the baseline period affected by climate change. 
There is a decline in the average rainfall from November to May, and rise from June to October (figure 13). In other words, there is a shift from winter and fall to summer. The changes in rainfall are almost the same under scenarios of A2 and $\mathrm{A} 1 \mathrm{~B}$, however, which is not the case for the B1 scenario. The average change in rainfall is between $-44 \%$ and $+9 \%$ for the period $2020-2044$, whereas the largest variation occurs in September and December.

\subsection{Impact of climate change on groundwater}

The results show that the pattern of changes in recharge follows the rainfall patterns. There is an increase in recharge from June to October and the largest reduction occurs in May. The amount of recharge differs in different sub-plains when groundwater balance components vary in each sub-plain. For example, precipitation is the only source of recharge in the Lor sub-plain whereas both precipitation and irrigation system can contribute to the groundwater balance in other sub-plains. As a result, the average monthly recharge varies between $+16 \%$ and $+74 \%$ in the Lor sub-plain while it varies between $+2 \%$ and $+14 \%$ in the western-Dez-plain.

The results revealed that there is a decline in water table in all the sub-plains except in the Deymche sub-plain (figure 14). The maximum and minimum decline in water table occurs in October and September, respectively. This is due to the shift in precipitation from winter to the late summer which results in more infiltration in August, and consequently more influence on water table in the following month.

The maximum and minimum decline in groundwater level occurs in the Sabili sub-plain (80 $\mathrm{cm})$ and the Deymche sub-plain $(2 \mathrm{~cm})$, respectively, which is associated with contributions of the groundwater components to the groundwater balance in each plain (figure 11). As a result, a small percentage of change in recharge can lead to a significant change in the absolute amount of recharge

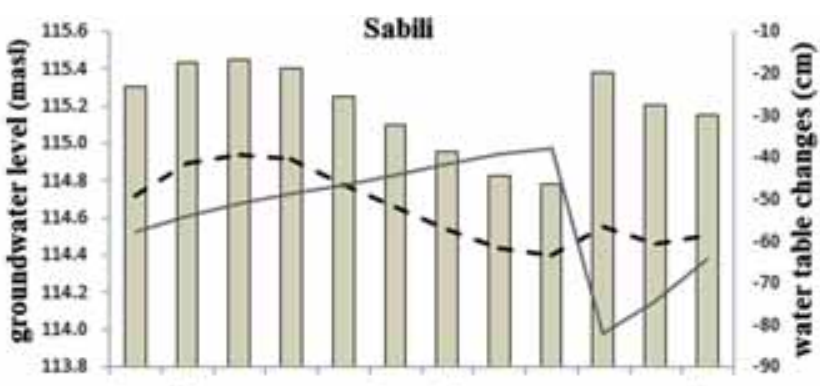

jan feb mar ape may jun jul aug sep oct nov dec

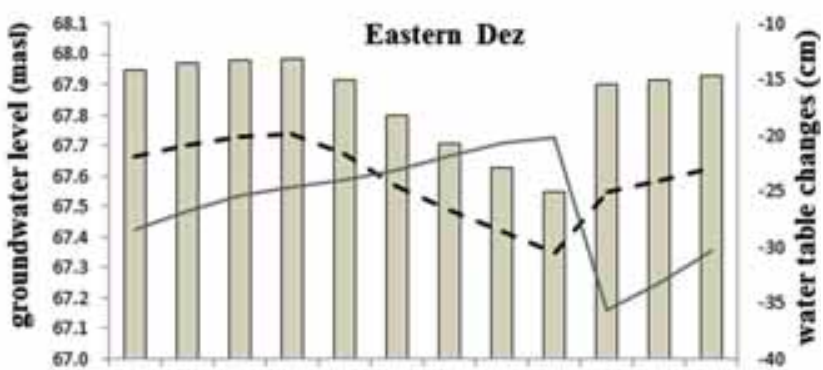

jan feb mar apr may jun jul aug sep oct nov dec

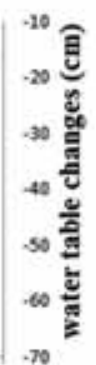

है
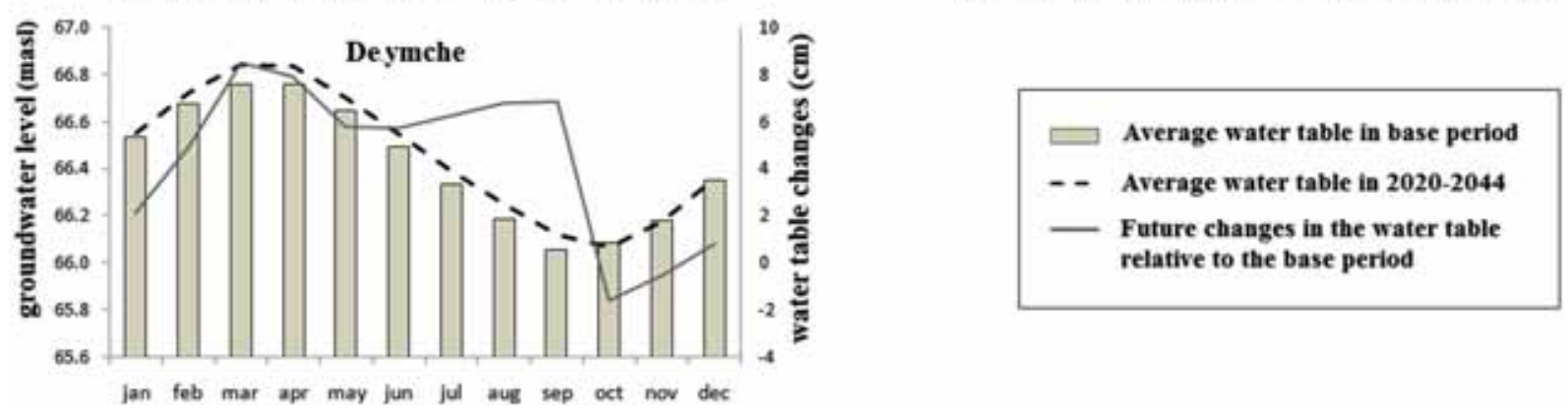

Figure 14. Groundwater level changes in the future compared to the base period affected by climate change. 

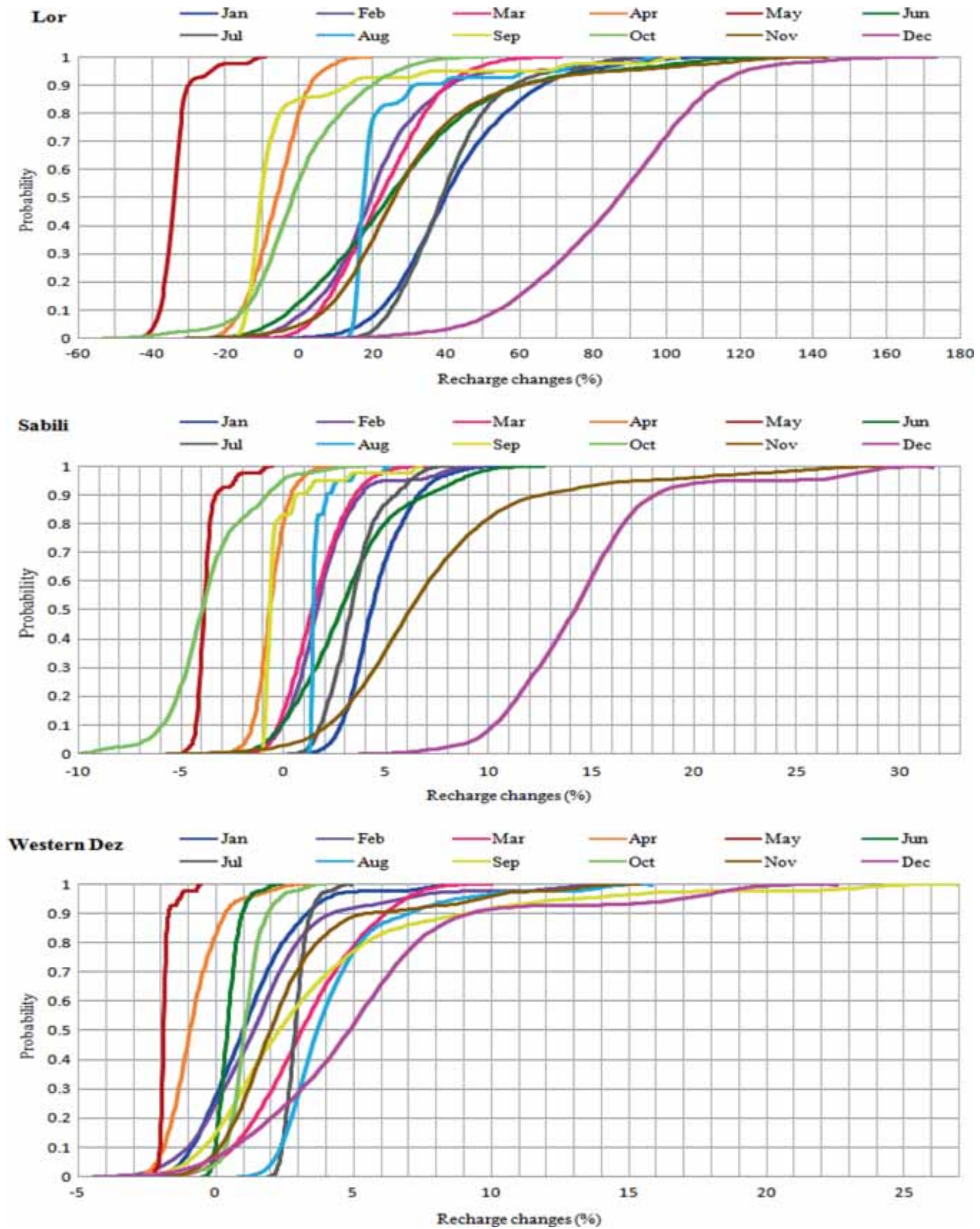

Figure 15. The uncertainty of recharge changes in the period of 2020-2044 compared to the baseline period. 

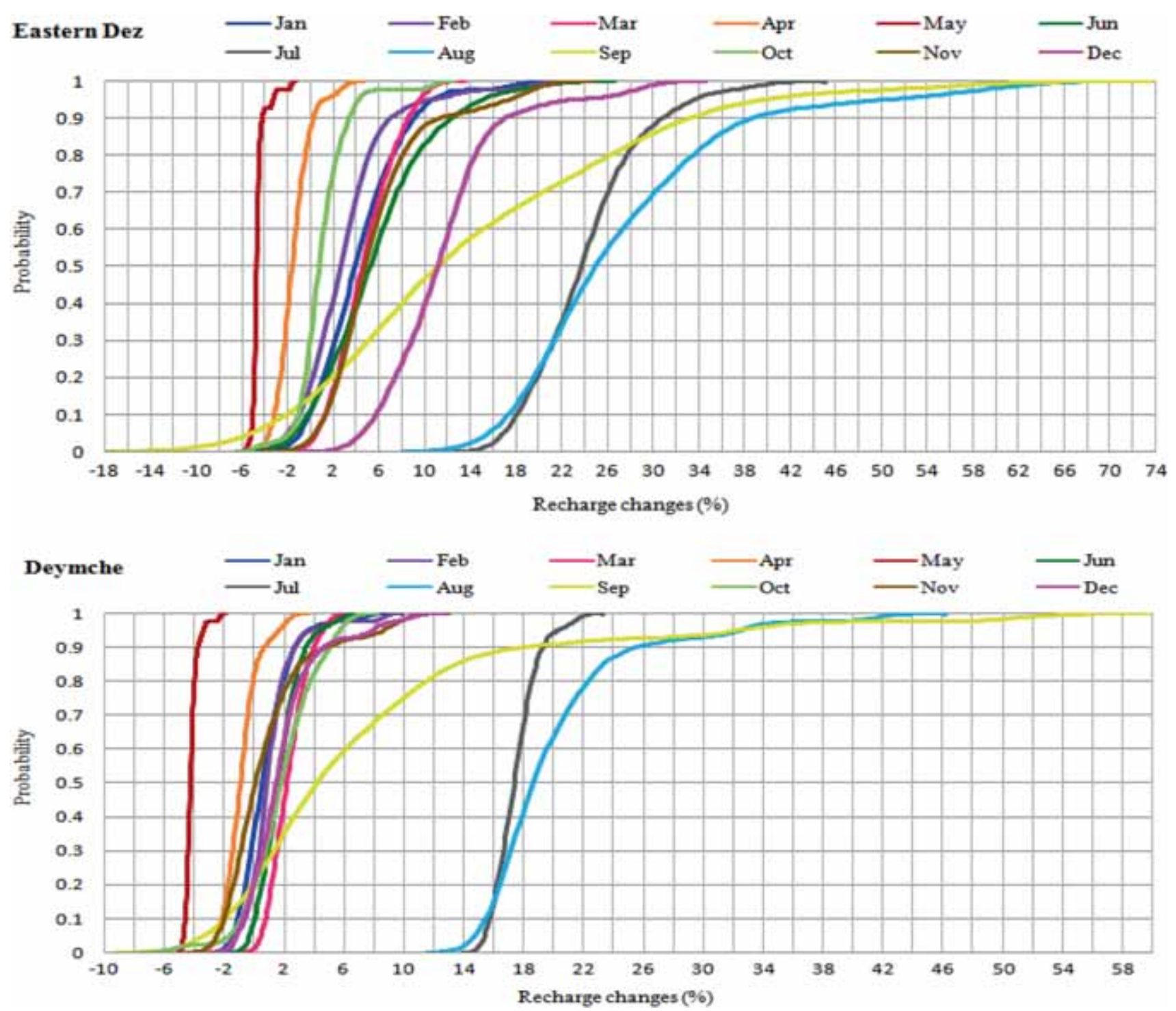

Figure 15. (Continued.)

in the Sabili sub-plain compared to the Deymche sub-plain.

Changes in groundwater levels in future, especially in the Damekesh Plain, which has the highest water loss, could lead to a change in the hydrological interactions between the river and aquifer. Although the aquifer system in the study area is less affected by climate change, the discharge from the aquifer and artificial nutrition (by irrigation networks) by humans are much more than the role of climate change. As a result, there was a reduction of about $8 \mathrm{~m}$ in the water table in some parts of the plain from 2006 to 2012, which is a threat to groundwater sustainability in the region. On the other hand, discharges from several irrigation networks and canals that return agricultural water into the aquifer could considerably affect the quality of groundwater as well. This is particularly the case in the sugarcane cultivation areas with the possibility of an increase in the salinity of the aquifer.

\subsection{Assessment of uncertainties}

Probability levels were estimated for each plain using the most appropriate PDF, the kernel method (figure 15). There is a decrease in recharge in April, May, June and October in the Dezful plain, in all risk levels. The largest rise $(40 \%)$ in recharge occurs in August. The most uncertainties were determined in September and December. Recharge varies between $-10 \%$ and $+13 \%$ in the Sabili plain, $-6 \%$ and $+10 \%$ in the Deymche plain, $-4 \%$ and $+10 \%$ in the western-Dez plain, and $-6 \%$ 
and $+26 \%$ in the eastern-Dez plain. The most pronounced changes (from $-40 \%$ to $+100 \%$ ) occur in the Lore plain. Figure 15 illustrates the variation of recharge and its risk level in the plain which could be a useful indicator for water management and planning in the region.

\section{Conclusion}

The impact of climate change on the groundwater system of the Dezful plain was investigated under 15 GCM scenarios from 2020 to 2044. Results revealed that the largest increase in temperature occurs in May while the largest decrease occurs in January and October. In other words, the rise in temperature is more pronounced in the wet season compared to the dry season. There is a shift in precipitation from fall to the late summer. The largest change in precipitation occurs in August.

The pattern of change in recharge follows the precipitation pattern of change. There is a decrease in recharge in April, May, June and October. The largest change in recharge occurs by $40 \%$ in the late summer whereas the most pronounced changes occur in the Lor plain. The largest uncertainty in the simulation of recharge under GCM scenarios was determined in August, September and December. The range of changes in recharge was determined between $-10 \%$ and $+13 \%$ in the Sabili plain, $-6 \%$ and $+10 \%$ in the Deymche plain, $-4 \%$ and $+10 \%$ in the western-Dez plain, and $-6 \%$ and $+26 \%$ in the eastern-Dez plain. The largest decline in groundwater level occurs in the Sabili plain in September. This study highlights that climate change can have a significant effect on groundwater resources in the region which reinforces the need for groundwater management plans and a long-term perspective.

\section{Acknowledgements}

We would like to thank the Khuzestan Water and Power Authority for providing the data for this study. We also thank the anonymous reviewers for their helpful suggestions in improving the paper.

\section{Appendix A1}

Table A1 indicates the pumping test information from 11 wells. The specific yield and transmissivity parameters were estimated using Theis and Cooper-Jacob methods. $X, Y$ and $T$ are assigned coordinates (UTMx and UTMy) and transmissivity $\left(\mathrm{L}^{2} / \mathrm{T}\right)$, respectively, for 11 pumping test wells.

\section{Appendix A2}

The emissions scenarios of the Special Report on Emissions Scenarios (SRES) (IPCC 2007) are given as follows:

A2: The A2 storyline and scenario family describes a very heterogeneous world. The underlying theme is self-reliance and preservation of local identities. Fertility patterns across regions converge very slowly, which results in continuously increasing population. Economic development is primarily regionally oriented and per capita economic growth and technological change more fragmented and slower than other storylines.

B1: The B1 storyline and scenario family describes a convergent world with the same global population, which peaks in mid-century and declines thereafter, as in the A1 storyline, but with rapid change in economic structures towards a service and information economy, with reductions in material intensity and the introduction of clean and resource-efficient technologies. The emphasis is on global solutions to economic, social and environmental sustainability, including improved equity, but without additional climate initiatives.

A1: The A1 storyline and scenario family describes a future world of very rapid economic growth, global population that peaks in midcentury and declines thereafter, and the rapid introduction of new and more efficient technologies. Major underlying themes are convergence among regions, capacity building and increased cultural and social interactions, with a substantial reduction in regional differences in per capita income. The A1 scenario family develops into three groups that describe alternative directions of technological change in the energy system. The three A1 groups are distinguished by their technological emphasis: fossil intensive (A1FI), non-fossil energy sources (A1T) or a balance across all sources (A1B) (where balanced is defined as not relying too heavily on one particular energy source, on the assumption that similar improvement rates apply to all energy supply and end-use technologies). 
Table A1. Transmissivity calculated from 11 pumping test wells.

\begin{tabular}{rccccrr}
\hline Number & $X$ & $Y$ & $\begin{array}{c}T \\
(\text { Theis })\end{array}$ & $\begin{array}{c}T \\
\text { (Cooper-Jacob) }\end{array}$ & $\begin{array}{c}\text { Average } T \\
\left(\mathrm{~m}^{2} / \text { day }\right)\end{array}$ & $\begin{array}{c}\text { Depth } \\
(\mathrm{m})\end{array}$ \\
\hline 1 & 234,799 & 3586,951 & 1115 & 1067 & 1100 & 80 \\
2 & 262,906 & 3572,635 & 7000 & - & 7000 & 145 \\
3 & 257,939 & 3567,706 & - & 12,220 & 13,000 & 80 \\
4 & 265,253 & 3571,561 & 15,400 & 15,061 & 15,000 & 93 \\
5 & 259,800 & 3556,504 & - & 6729 & 6500 & 85 \\
6 & 253,457 & 3573,052 & 15,429 & 14,465 & 15,000 & 89 \\
7 & 244,788 & 3555,903 & 6256 & 4851 & 6000 & 107 \\
8 & 246,491 & 3570,214 & - & 8000 & 8000 & 92 \\
9 & 246,355 & 3582,110 & - & 28,500 & 28,500 & 87 \\
10 & 257,292 & 3580,451 & - & 2451 & 2451 & 95 \\
11 & 250,740 & 3599,706 & - & 509 & 580 & 140 \\
\hline
\end{tabular}

\section{References}

Adams K D and Sada D W 2014 Surface water hydrology and geomorphic characterization of a playa lake system: Implications for monitoring the effects of climate change; J. Hydrol. 510 92-102.

Ali R, McFarlane D, Varma S, Dawes W, Emelyanova I, Hodgson G and Charles S 2012 Potential climate change impacts on groundwater resources of south-western Australia; J. Hydrol. 475 456-472.

Aronica G, Corrao C, Amengual A, Alonso S and Romero R 2005 Water resources evaluation under climatic trend effects in Mediterranean catchments; Geophys. Res. Abstr. 704091.

Banta E R 2000 MODFLOW-2000, the U.S. Geological Survey Modular Groundwater Model-Documentation of Packages for Simulating Evapotranspiration with a Segmented Function (ETS1) and Drains with Return Flow (DRT1); US Geological Survey, Denver, Colorado.

Barnett T, Malone R, Pennell W, Stammer D, Semtner B and Washington W 2004 The effects of climate change on water resources in the west: Introduction and overview Clim. Change 62 1-11.

Candela L, Elorza F J, Jiménez-Martínez J and Igel W V 2012 Global change and agricultural management options for groundwater sustainability; Comput. Electron. Agric. 86 120-130.

Changxing S, Yuanyuan Z, Xiaoli F and Wenwei S 2013 A study on the annual runoff change and its relationship with water and soil conservation practices and climate change in the middle Yellow River basin; Catena 100 31-41.

Chen Z, Huang Y, Ling M, Hu Q and Lio B 2012 Numerical modeling groundwater recharge and its implication in water cycles of two interdunal valleys in the Sand Hills of Nebraska; Phys. Chem. Earth 53-54 10-18.

Chen T F, Wang X S, Li H, Jiao J J and Wan L 2013 Redistribution of groundwater evapotranspiration and water table around a well field in an unconfined aquifer: a simplified analytical model; J. Hydrol. 495 162-174.

Claudia A, Braga M, Silva R M d, Santos C A G, Galvao C d O and Nobre P 2013 Downscaling of a global climate model for estimation of runoff, sediment yield and dam storage: A case study of Pirapama basin, Brazil; J. Hydrol. $49846-58$

Cooper H H and Jacob C E 1946 A generalized graphical method for evaluating formation constants and summarizing well field history; Trans. Am. Geophys. Union $\mathbf{2 7}$ 526-534.

Coppola E A Jr, Duckstein L and Davis D 2002 Fuzzy rulebased methodology for estimating monthly groundwater recharge in a temperate watershed; J. Hydrol. Eng. $7(4)$ 326-335.

Doherty J 2015 Calibration and Uncertainty Analysis for Complex Environmental Models; Watermark Numerical Computing, Brisbane. ISBN: 978-0-9943786-0-6.

Eckhardt K and Ulbrich U 2003 Potential impacts of climate change on groundwater recharge and stream flow in a central European low mountain range; J. Hydrol. 284 $244-252$.

Ekström M, Fowler H J, Kilsby C G and Jones P D 2005 New estimates of future changes in extreme rainfall across the UK using regional climate model integrations. 2. Future estimates and use in impact studies; J. Hydrol. 300234 251.

Farjad B, Gupta A and Marceau D J 2016 Annual and seasonal variations of hydrological processes under climate change scenarios in two sub-catchments of a complex watershed; Water Resour. Manag. 30(8) 2851-2865.

Forsythe N, Fowler H J, Blenkinsop S, Burton A, Kilsby C G, Archer D R, Harpham C and Hashmi M Z 2014 Application of a stochastic weather generator to assess climate change impacts in a semi-arid climate: The upper Indus basin; J. Hydrol. 517 1019-1034.

Froukh L J 2002 Groundwater modelling in aquifers with highly karstic and heterogeneous characteristics (KHC) in Palestine; Water Resour. Manag. 16(5) 369-379.

Gao H 2011 Groundwater modeling for flow systems with complex geological and hydrogeological conditions; In: 2011 Xi'an International Conference on Fine Geological Exploration and Groundwater $\&$ Gas Hazards Control in Coal Mines, Procedia Earth and Planetary Science, pp. 23-28.

Gerner A, Schütze N and Schmitz G H 2012 Portrayal of fuzzy recharge areas for water balance modelling - a case study in northern Oman; Adv. Geosci. 31(31) 1-7. 
Goderniaux P, Brouyère S, Fowler H J, Blenkinsop S, Therrien R, Orban P and Dassargues A 2009 Large scale surface-subsurface hydrological model to assess climate change impacts on groundwater reserves; J. Hydrol. 373 $122-138$.

Green T R, Taniguchi M, Kooi H, Gurdak J J, Allen D M, Hiscock K M, Treidel H and Aureli A 2011 Beneath the surface of global change: Impacts of climate change on groundwater; J. Hydrol. 405 532-560.

Grillakis M G, Koutroulis A G and Tsanis I K 2011 Climate change impact on the hydrology of spencer creek watershed in Southern Ontario, Canada; J. Hydrol. 409(1) $1-19$

Hantush M S 1961 Aquifer tests on partially penetrating wells; J. Hydraul. Div. 87(5) 171-195.

Hellmann F and Vermaat J E 2012 Impact of climate change on water management in Dutch peat polders; Ecol. Model. $24074-83$.

Hewitson B C and Crane R G 2006 Consensus between GCM climate change projections with empirical downscaling: Precipitation downscaling over South Africa; Int. J. Climatol. 26(10) 1315-1337.

Hosseinizadeh A, SeyedKaboli H, Zareie H, Akhondali A and Farjad B 2015 Impact of climate change on the severity, duration, and frequency of drought in a semi-arid agricultural basin; Geoenviron. Disasters 2(1) 1-9.

IPCC 2007 Climate change 2007: The physical science basis-summary for policymakers; Contribution of Working Group I to the Fourth Assessment Report of the Intergovernmental Panel of Climate Change, IPCC, Geneva.

IPCC 2013 Working Group I contribution to the IPCC Fifth Assessment Report Climate Change 2013: The Physical Science Basis-Summary for Policymakers; Intergovernmental Panel of Climate Change (IPCC), Stockholm.

Jackson C R, Meister R and Prudhomme C 2011 Modeling the effects of climate change and its uncertainty on UK chalk groundwater resources from an ensemble of global climate model projections; J. Hydrol. 399 12-28.

Jang C S, Liu C W and Chou Y L 2012 Assessment of groundwater emergency utilization in Taipei basin during drought; J. Hydrol. 414-415 405-412.

Jyrkama M I and Sykes J F 2007 The impact of climate change on spatially varying groundwater recharge in the grand river watershed (Ontario); J. Hydrol. 338 237250.

Khadri S F I and Pande C 2016 Ground water flow modeling for calibrating steady state using MODFLOW software: A case study of Mahesh River basin, India; Model. Earth. Syst. Environ. 2(1) 1-17.

Klir G and Yuan B 1995 Fuzzy Sets and Fuzzy Logic; Vol. 4, Prentice Hall, New Jersey.

Kløve B, Ala-aho P, Bertrand G, Boukalova Z, Ertürk A, Goldscheider N, Ilmonen J, Karakaya N, Kupfersberger H, Kvoerner J, Lundberg A, Mileusniüć, M, Moszczynska A, Muotka T, Preda E, Rossi P, Siergieiev D, Šimek J, Wachniew P, Angheluta V and Widerlund A 2011 Groundwater dependent ecosystems. Part I: Hydroecological status and trends; Environ. Sci. Policy 14 770-781.

Kobierska F, Jonas T, Zappa M, Bavay M, Magnusson J and Bernasconi S M 2013 Future runoff from a partly glacierized watershed in Central Switzerland: A tow model approach; Adv. Water Resour. 55 204-214.
Konig L F and Weiss J L 2008 Groundwater: Modeling, Management and Contamination; Nova Science Publishers, Inc, New York.

Kundzewicz Z W, Mata L J, Arnell N W, Doll P, Jimenez B, Miller K, Oki T, Şen Z and Hiklomanov I 2008 The implications of projected climate change for freshwater resources and their management; Hydrol. Sci. J. 53(1) $3-10$.

Kurylyk B L and MacQuarrie K T B 2013 The uncertainty associated with estimating future groundwater recharge: A summary of recent research and an example from a small unconfined aquifer in a northern humid-continental climate; J. Hydrol. 492 244-253.

Laprise R 2008 Regional climate modeling; J. Comput. Phys. 227 3641-3666.

Li H T, Kinzelbach W, Brunner P, Li W P and Dong X G 2008 Topography representation methods for improving evaporation simulation in groundwater modeling; J. Hydrol. 356 199-208.

Liu H H 2011 Impact of climate change on groundwater recharge in dry areas: An ecohydrology approach; J. Hydrol. 407 175-183.

Luo Y, Khan S, Peng S, Rana T, Wang W and Jiang Y 2012 Effects of the discretisation cell size on the output uncertainty of regional groundwater evapotranspiration modeling; Math. Comput. Model. 56 1-13.

Maurer E P 2007 Uncertainty in hydrologic impacts of climate change in the Sierra Nevada, California, under two emissions scenarios; Clim. Change 82(3-4) 309-325.

McDonald M G and Harbaugh A W 1988 A modular three-dimensional finite-difference ground-water flow model; Techniques of water-resources investigations of the United States geological survey, Book 6, Chapter A1, $586 \mathrm{p}$.

Minville M, Brissette F and Leconte R 2008 Uncertainty of the impact of climate change on the hydrology of a nordic watershed; J. Hydrol. 358(1) 70-83.

Murphy J M, Sexton D M, Barnett D N, Jones G S, Webb M J, Collins M and Stainforth D A 2004 Quantification of modelling uncertainties in a large ensemble of climate change simulations; Nature 430(7001) 768-772.

Pavelic P, Srisuk K, Saraphirom P, Nadee S, Pholkern K, Chusanathas S, Munyou S, Tangsutthinon T, Intarasut $\mathrm{T}$ and Smakhtin $\mathrm{V} 2012$ Balancing-out floods and droughts: Opportunities to utilize floodwater harvesting and groundwater storage for agricultural development in Thailand; J. Hydrol. 470-471 55-64.

Prudhomme C, Jakob D and Svensson C 2003 Uncertainty and climate change impact on the flood regime of small UK catchments; J. Hydrol. 277 1-23.

Quevauviller P 2011 Adapting to climate change: Reducing water-related risks in Europe - EU policy and research considerations; Environ. Sci. Policy 14 722-729.

Ranjan P, Kazama S and Sawamoto M 2006 Effects of climate change on coastal fresh groundwater resources; Global Environ. Change 16 388-399.

Rojas R and Dassargues A 2007 Groundwater flow modeling of the regional aquifer of the Pampa del Tamarugal, northern Chile; Hydrol. J. 15 537-551.

Scibek J, Allen D M, Cannon A J and Whitfield P H 2007 Groundwater-surface water interaction under scenarios of 
climate change using a high-resolution transient groundwater model; J. Hydrol. 333 165-181.

Semenov M A and Barrow E M 2002 LARS-WG, A Stochastic Weather Generator for Use in Climate Impact Studies, User Manual; Hertfordshire, UK.

Semenov M A and Stratonovitch P 2010 Use of Multi-model Ensembles from Global Climate Models for Assessment of Climate Change Impacts; Clim. Res. 41 1-14.

Singh A 2013 Groundwater modeling for the assessment of water management alternatives; J. Hydrol. 481 220-229.

Solaiman T A and Simonovic S P 2011 Development of probability based intensity-duration-frequency curves under climate change; Water Resources Research Report No. 072, Facility for Intelligent Decision Support, Department of Civil and Environmental Engineering, London, Ontario, Canada, 93p, ISSN: (print) 1913-3200; (online) 1913-3219.

Stoll S, Hendricks F H J, Butts M and Kinzelbach W 2011 Analysis of the impact of climate change on groundwater related hydrological fluxes: A multi-model approach including different downscaling methods; Hydrol. Earth Syst. Sci. 15(1) 21-38.

Thangarajan M 2007 Groundwater Resource Evaluation, Augmentation, Contamination, Restoration, Modeling and Management; Springer, 362p.
Touhami I, Chirino E, Andreu J M, Sánchez J R, Moutahir $\mathrm{H}$ and Bellot J 2015 Assessment of climate change impacts on soil water balance and aquifer recharge in a semiarid region in south east Spain; J. Hydrol. 527 619629.

Van Pelt S C and Swart R J 2011 Climate change risk management in transnational river basins: The rhine; Water Resour. Manag. 25 3837-3861.

VanRoosmalen L, Sonnenborg T O and Jensen K H 2009 Impact of climate and land use change on the hydrology of a large-scale agricultural catchment; Water Resour. Res. 45(7), https://doi.org/10.1029/2007WR006760.

Vicuna S, Maurer E P, Joyce B, Dracup J A and Purkey D 2007 The sensitivity of California water resources to climate change scenarios; J. Am. Water Resour. Assoc. 43(2) 482-498.

Wilby R L and Harris I 2006 A frame work for assessing uncertainties in climate change impacts: Low flow scenarios for the River Thames, UK; Water Resour. Res. 42 10p, W02419, https://doi.org/10.1029/ 2005WR004065.

Zhao Y, Camberlin P and Richard Y 2005 Validation of a coupled GCM and projection of summer rainfall change over South Africa, using a statistical downscaling method; Clim. Res. 28 109-122.

Corresponding editor: RAJIB MAITY 